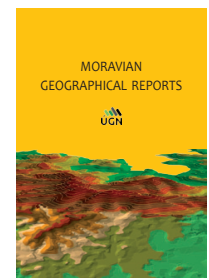

MORAVIAN GEOGRAPHICAL REPORTS

The Czech Academy of Sciences, Institute of Geonics

journal homepage: http://www.geonika.cz/mgr.html

doi: https://doi.org/10.2478/mgr-2021-0008

\title{
Conflicting imaginaries in the energy transition? Nature and renewable energy in Iceland
}

\author{
Karl BENEDIKTSSON ${ }^{\text {** }}$
}

\begin{abstract}
An improved understanding of the geographical unevenness of the global energy transition is important. The concept of 'sociotechnical imaginaries' has been used extensively for understanding how desired technology futures are envisioned and differentially articulated in various contexts. Supplementing this, the concept of 'nature imaginaries' is proposed in this article, to specifically address collective moral visions of human/nature relations that underwrite discourses and actions by various actors. Nature plays an active role in both types of imaginaries. Their complex interactions play a part in how energy transitions unfold. The article uses this framework for a description of the energy situation in Iceland, and its largely successful transition towards renewable energy through the development of hydropower and geothermal resources. Particular sociotechnical and nature imaginaries, sometimes opposed to each other, are discernible. The article argues that the analysis of conflicting imaginaries at work in specific energy transitions might help in identifying leverage points from where it is possible to work in a small way towards a global transition.
\end{abstract}

Keywords: sociotechnical imaginary, nature imaginary, energy transition, renewable energy, energy landscape, Iceland

Article history: Received 7 October 2020, Accepted 11 January 2021, Published 30 June 2021

\section{Introduction: \\ Understanding energy transitions}

In response to human-induced climate change, the world has taken a turn towards a low-carbon future. Renewable energy installations have grown considerably worldwide over the past decade (IRENA, 2020), and states have adopted a variety of policy instruments to encourage their deployment (Carley et al., 2017). It seems that the energy transition is proceeding at full speed.

Or, perhaps, not quite. Arguably there is no such thing as 'the' energy transition. Rather, various local and national transitions are underway (Sarrica et al., 2016; Labussière and Nadaï, 2018; Frantál and Nováková, 2019) - some reasonably fast, others excruciatingly slow, emphasising different technologies and institutional structures, and reflecting differing public concern and political will (Neofytou et al., 2020; Svobodova et al., 2020). Take, for instance, Germany's early and vigorous adoption of the concept of the Energiewende (Steinbacher, 2019) versus the stubborn adherence to coal by policy makers in neighbouring Poland (Kuchler and Bridge, 2018), and in a host of other 'recalcitrant nations' (Svobodova et al., 2020), including China and the United States - the world's principal $\mathrm{CO}_{2}$-emitters.
Understanding this diversity of energy transitions requires not only an awareness of varied natural conditions and historical particularities, but also of ways in which the future of energy systems is collectively envisaged in different manners in various cultural contexts (Delina and Janetos, 2018). Such envisaged futures - or 'imaginaries' generate public support for some technological or organisational innovations but can hold back the development of others. In this article, it is hypothesised that such different and sometimes incompatible cultural constructs can influence the progress towards carbonneutral energy production. The alignment or mismatch between imaginaries that focus on different aspects might partly explain the different paths taken by energy transitions in different countries and regions.

The primary focus of this article is on the exploration of the general value of imaginaries for analysing energy transitions. The general theoretical position is elaborated at some length in the first part. The starting point will be the concept of 'social imaginaries', which has a long history in the social sciences (see Strauss, 2006, for an overview of key contributions). Building on that foundation, the idea of 'sociotechnical imaginaries' was suggested by Jasanoff and

\footnotetext{
${ }^{a}$ Department of Geography and Tourism, Faculty of Life and Environmental Sciences, University of Iceland, Reykjavik, Iceland (*corresponding author: K. Benediktsson, e-mail: kben@hi.is)
} 
Kim (2009) for directing attention to nation-specific ways of imagining technological developments into the future. Having outlined this concept as it was originally formulated, I suggest that other - yet related - imaginaries can also play an important part, notably how ideal human relations with nonhuman nature are morally imagined, often at scales other than the national. These I will term 'nature imaginaries'. By speaking of 'nature' rather than 'environment' (cf. Peet and Watts, 1996), the intention is to allow room for non-human matter in its varied forms as active in the formation of such imaginaries. Indeed, in much recent theoretical work (see e.g. Bennett, 2004; Latour, 2005; Coole and Frost, 2010; DeLanda, 2016), agency has been conceptualised as a relational achievement between heterogenous entities of diverse kinds.

In the second part, the hypothesis of aligning or mismatching imaginaries is explored further through a description of the history and current situation of renewable energy in Iceland, a country where renewable energy is particularly abundant, and which is often noted for the high proportion of renewables in its energy mix. Prevailing sociotechnical and nature imaginaries are identified and their relations to each other are discussed. This part is based on previous research by the author (Benediktsson, 2007, 2008, 2014, 2018; Benediktsson and Waage, 2018, 2020), as well as other scholars. The database timarit.is was used to search for examples from printed media in Iceland, and general web searches returned further evidence from digital publications and other sources.

The article concludes with some thoughts about the implications and potential practical significance of this approach for the analysis of energy transitions in general In short, the argument is that, if the hypothesis is true, advancing the ongoing transition to renewable energy may in some geographical contexts require a critical reconsideration of established imaginaries and even the cultivation of new ones.

\section{Imaginaries and energy}

\subsection{Imagining the social}

Attention to the imaginary dimension of society has a considerable history (see e.g. Anderson, 1983; Castoriadis, 1987; Appadurai, 1996). Very broadly speaking, two distinct emphases are discernible (Strauss, 2006). Both are concerned with analysing how the desired future is envisaged by social groups - of what the good and morally proper life should look like in years and decades to come. On the one hand, some scholars have theorised the social imaginary as "a unifying factor that provides a signified content and weaves it with the symbolic structures" (Castoriadis, 1987, p. 160): a common mindset that has been gradually articulated by a large collectivity - such as the nation - and adopted more or less in unison. Others, for example, Taylor (2004), have worked with the concept in a way that leaves more room for diversity, putting more emphasis on the imaginary as a construct of groups, small or large, rather than a broad abstraction at the national level. Taylor understands the social imaginary as "the ways in which people imagine their social existence, how they fit together with others, how things go on between them and their fellows, the expectations that are normally met, and the deeper normative notions which underlie these expectations" (Taylor, 2004, p. 23). It is deeply interwoven with practice, as it provides "that common understanding that makes possible common practices and a widely shared sense of legitimacy" (Taylor, 2004, p. 23). The scale of such collective imagining can range from small groups of people to the national or supranational level.

\subsection{Imaginaries of technology and society}

Technological choice and development are perforce future-oriented. Historians of technology and culture (e.g. Marx, 1964; Nye, 1990) have written insightful accounts of the uptake of particular technologies, and the role that popular and/or political visions and imaginings have played. They have warned against the idea that technology per se is the driving force of social change (Smith and Marx, 1994). For a long time, scholars of science and technology studies (STS) have also studied the role of imagination in technological and scientific development. The imaginings of scientists themselves have been extensively studied, for instance through the concept of 'technoscientific imaginaries' (Marcus, 1995). STS researchers have thus sometimes concentrated more on how technoscientific knowledge is produced by specific people at particular sites, such as in the laboratory (Latour, 1987), than on how such knowledge is imbricated with wider political processes and institutions. This runs the risk of a certain 'power blindness', which is partly what Jasanoff and Kim (2009) intended to rectify.

In their early writings on sociotechnical imaginaries, Jasanoff and Kim (2009, p. 120) define them as "collectively imagined forms of social life and social order reflected in the design and fulfilment of nation-specific scientific and/ or technological projects" that "at once describe attainable futures and prescribe futures that states believe ought to be attained". As this suggests, they focus on the national level and the tasks and capacities of the state. Sociotechnical imaginaries influence the setting of policy priorities, which again reinforce or change prevailing imaginaries.

While this may run the risk of reifying the state, the concept is offered as a corrective to the tendency to ascribe imagining to selected individuals, notably in the STS context to scientists and technology experts. By contrast, what sociotechnical imaginaries highlight is the collective side of imagination. In a subsequent edited book on the concept, Jasanoff $(2015$, p. 4) reformulates the original definition in a little more nuanced way: "collectively held, institutionally stabilised, and publicly performed visions of desirable futures, animated by shared understandings of forms of social life and social order attainable through, and supportive of, advances in science and technology". This opens up the question for such collective imaginary work not only at the state level, but in various other social bodies as well, e.g. in advocacy groups, conservation organisations and other collectives.

Sociotechnical imaginaries are "imbued with implicit understandings of what is good or desirable in the social world writ large" (Jasanoff and Kim, 2009, pp. 122-123); hence they function as a guide into the future to attain 'the good life'. Such prescriptions are found in many places - in rather concrete forms in policy agendas and documents, as well as in media discourses; and in very basic terms both in religious beliefs and secular, usually unquestioned, cultural blueprints, such as the grand narrative of modernity and progress. Sociotechnical imaginaries encompass all these dimensions yet are somehow different: they are found "in the understudied regions between imagination and action, between discourse and decision, and between inchoate public opinion and instrumental state policy" (Jasanoff and Kim, 2009, p. 123) 
The concept has been employed in a variety of case studies, involving different technological spheres and geographical contexts (see e.g. Jasanoff and Kim, 2015), proving its value for understanding not only how new ideas in science and technology are taken up and gain ground, but also how they come to be embedded in and expressed through material, institutional and cultural processes. Sometimes such ideas are extended into other fields and spaces, but they are also frequently contested and resisted. The concept has in fact been criticised for not handling diversity and contestation very successfully: "the analytic tool is calibrated to understand national policies, institutions, and elites" (Smith and Tidwell, 2016, p. 331) and "leaves undertheorized how differently positioned communities within sociotechnical systems imagine good societies" (Smith and Tidwell, 2016, p. 328). While it does not invalidate the core of the sociotechnical imaginaries concept, this is a very important critique which supports the analysis of multiple, diverse imaginaries.

\subsection{Energy futures imagined}

The original discussion of sociotechnical imaginaries by Jasanoff and Kim (2009) centred on nuclear energy - a hi-technology field that has developed in widely divergent ways in those countries which have embarked on it. Few topics in fact lend themselves better to the analysis of this kind than energy technologies. To take but one example, in their analysis of US energy history, Sovacool and Brossmann (2013) show how the advent of not only nuclear technology in the post-WWII era, but also the introduction of hydropower plants for electricity and the internal combustion engine for transport decades earlier, gave rise to certain socially articulated visions of the future. Now the focus has shifted decisively to renewable energy technologies. In a similar manner, the ways in which such technologies are taken up, imagined and included in a narrative of the future are at the core of the contemporary energy transition. Many researchers have already addressed this topic, analysing collectivities ranging from the multinational to the local and urban, and involving different energy sources and technologies (e.g. Eaton et al., 2014; Smith and Tidwell, 2016; Burnham et al., 2017; Cloke et al., 2017; Delina, 2018; Kuchler and Bridge, 2018; Schelhas et al., 2018; Tidwell and Tidwell, 2018; Tozer and Klenk, 2018; Longhurst and Chilvers, 2019).

The transition towards renewables involves "reconfiguring current spatial patterns of economic and social activity" (Bridge et al., 2013, p. 331). An important part of this centres on landscape and nature. Most renewable technologies impact profoundly on the landscape (Apostol et al., 2017; Roth et al., 2018). This impact varies considerably, however, in accordance with the differing energy densities and other characteristics of the source being utilised (Pasqualetti and Stremke, 2018). Despite the advice that humans should simply 'learn to love' the new 'landscapes of carbonneutrality' (Selman, 2010), recurring disputes around various renewable energy projects show a mismatch between the ideas about technical development and human-nature relations.

The resolution of such contests is ultimately the subject of the political sphere. In their analysis of the emergent bioenergy economy in the north-eastern United States, Burnham et al. (2017) make an important point about the politics of imaginaries. In this case, two contending sociotechnical imaginaries have taken shape, one focused on regional production with corporate involvement, and the other on the community level. The authors show how the participants in the discussion about bioenergy futures "connect issues of technological choice, economic organisation, and land use decisions to their sociotechnical imaginary" (Burnham et al., 2017, p. 74) in widely different ways. At stake are basic visions of how society should be organised and how land should be used.

Recognising the politics of competing sociotechnical imaginaries is certainly a significant step towards understanding the geographical diversity of energy transitions. The strong focus on technology that is still inherent in the very concept of the sociotechnical imaginary, however, may be somewhat limiting: although technology itself can indeed be fundamentally understood as a way to deal with nature and exploit it for the benefit of humans, different ways of relating to nature do exist, which sometimes compete with the technical. Other collective imaginaries, sometimes having little to do with technology, but which focus on the environment - importantly including nonhuman nature - also manifest how ideal futures are envisaged.

\subsection{Imaginaries of environment and nature}

Geographers Peet and Watts (1996, p. 263) defined an 'environmental imaginary' as "a way of imagining nature, including visions of those forms of social and individual practice which are ethically proper and morally right with regard to nature." Coming to the topic from Marxist political economy and political ecology, they attempt to augment these bodies of scholarship with insights from poststructuralism, which emphasises discourse and power. Their approach stresses the social relations of production: environmental imaginaries are manifested in the "regional discursive formations" that "originate in, and display the effects of, certain physical, political-economic, and institutional settings" (Peet and Watts, 1996, p. 16).

Several researchers have picked up this concept. For instance, Nesbitt and Weiner (2001) analyse disputes in Appalachia between local landowners and environmentalists from outside the region, highlighting the conflict between very different environmental imaginaries articulated by the groups. McGregor (2004) shows how the environmental imaginaries of Australian environmentalists are constrained by the hegemony of 'sustainable development', the anthropocentrism of which, he argues, precludes the enunciation of more radical and ecocentric approaches. Other researchers have explored urban environmental imaginaries, both as a useful approach to critical urban research in general (Gabriel, 2014), and how the concept can be of value for particular cities (Millington, 2013).

To speak of 'imaginaries', of course, suggests a humancentred approach, which is further amplified by the 'environmental' qualifier. The emphasis on 'discourse' by Peet and Watts (1996), and most of those who have since used their concept for their own empirical studies, is also telling: discourse tends to be understood as human exchanges, representations, and social practices. Despite assertions to the contrary, therefore, the place of the non-human in environmental imaginary research generally seems to be more passive than active. This is somewhat problematic. While appreciating the all-too-real problems with speaking simplistically of 'nature', I would nevertheless try to work out the implications of talking about 'nature' imaginaries rather than 'environmental' ones. 
I propose that nature imaginaries be defined as particular, usually unarticulated, premises held by certain groups of people about how human-nonhuman relations should be structured in order to ensure a morally sound future. Such premises exert their influence on thinking, talk and action by diverse collectivities: the state, market actors, and perhaps most notably civil society groups. They surface in the actions and events in which the groups participate, as well as in discourses and documents. They are future-oriented, yet always influenced by past events and historical memory.

Crucially, nature imaginaries are also shaped by nonhuman nature itself, its events and agencies. Far from the reified meaning that often is taken for granted when speaking of nature, I take it to be a collection of "heterogeneous, diverse, and often whimsical things that comprise the physical environments of the world" (Kaika and Swyngedouw, 2011, p. 104); things that come together and exert their agencies in particular ways in different locations. In this way, nature is an assemblage that is endowed with 'thing-power': "a force exercised by that which is not specifically human (or even organic) upon humans" (Bennett, 2004, p. 351). Work in geography and other fields has indeed extended the list of living and non-living 'things' in nature that exert such power through their relations with other things in a hybrid world (Greenhough, 2014).

While the analysis of sociotechnical imaginaries tends to highlight the state, this may not necessarily be the most relevant level for investigating nature imaginaries. They may certainly be formulated and manifested in legislation and state policy documents, e.g. in conservation policies, but then often as a reflection of sentiments and ideals that have taken their shape in other spheres than national politics, e.g. in the research of conservation science or international agreements and conventions. Market actors whose operations are based on natural resources also operate with certain nature imaginaries, but the backdrop to these is usually the pressure to maintain future profitability. If this is seriously threatened, the imaginaries may be tweaked so as to allow for new arrangements for natural resource management.

Finally, clear indications of nature imaginaries at work may also be identified in civil society. For small local groups or communities, specific nature imaginaries may take some form in confrontation with sociotechnical visions and practices promoted by state or corporate actors. Debates around particular wind energy projects, for example, often reveal concerns about nature and landscape, albeit sometimes vaguely articulated, to be the main source of community opposition. As hinted at by Hunold and Leitner (2011), for example, in their discussion of solar thermal energy in Southern California, environmental concerns can also lead to the articulation and expression of local nature imaginaries that previously had not taken on a coherent form, although their basic building blocks may have existed. This will be explored further in the second part of this article.

One may legitimately ask whether the nature imaginary, as I have defined the concept, is not simply another name for ideas, beliefs, attitudes or values pertaining to nonhuman nature. The concept certainly relates to all these terms, yet it does not equate fully to any of them. A vast and very diverse set of studies of ideas about human-nonhuman relations already exists. On the one hand, research concerning environmental attitudes, values and beliefs has a long pedigree (Ignatow, 2006), as well as how or indeed whether environmental concerns affect behaviours (Stern, 2000). Most of this work is marked by methodological individualism - the usually unstated assumption that aggregations of individual characteristics can reveal truths about larger social collectivities. Examples include Catton and Dunlap's (1980) survey-based identification of two opposing paradigms: an old but still influential 'human exemptionalist' one and a 'new ecological' one. On the other hand, there are very broad-brush characterisations of cultural realms, based to some extent on historical evidence, such as White's muchcited thesis about the influence of Judeo-Christian beliefs on how human-nature relations have been envisaged in Western cultures (White, 1967), or the idea, popular some time ago, that certain perceptions of nature existed in Asian societies where philosophies of Buddhism, Daoism or Hinduism have been prominent (Rolston III, 1987). Both can be questioned for their rather sweeping generalisations. By keeping an eye on the collective basis of nature imaginaries, albeit at different collective scales, it should be easier to avoid either methodological individualism or unwarranted generalisation when analysing environmental beliefs and attitudes.

Much of the above-mentioned work has been clearly marked by dualisms: society vs. nature; matter vs. meaning, and so on. The suggestion above, that nature be understood as an assemblage of heterogenous 'things', is an attempt to avoid this. Grasped in this way, nature does not enter into imaginary work simply as a primordial entity to be subjected to human desires and moral imperatives in a passive manner: its diverse living and non-living entities wield their 'thingpower' through the affective responses of humans to them (Thrift, 2008; Clark, 2011; Petersen, 2018). Importantly, while affects are produced by individual sensory engagements, they are also "saturated with collective knowledge and values" (Petersen, 2018, p. 7). The nature imaginary may therefore be understood as a collective, more-than-human construction - or co-construction. When it comes to renewable energy projects, the form that construction takes is by no means a foregone conclusion, but the specific outcome of the affects of nature and their cultural collective processing.

An intriguing recent example from South Korea (Kim, Chung and Seo, 2018) well illustrates the complexity and cultural depth of nature imaginaries, although the authors do not use the term themselves. In this technologically advanced country, the age-old East Asian tradition of 'pungsu' (fengshui) is still very much alive. 'Pungsu' centres on the mapping and manipulation of 'qi', the vital energy thought to affect human life in many aspects. Sites where wind conditions are favourable for the location of wind turbines are considered inauspicious in 'pungsu' terms. The erection of such turbines is resisted and likened in fact to the attempt of the Japanese occupational forces to thwart the flow of 'qi' by driving iron stakes into mountains, thus breaking the spirit of the people. One could interpret this as a very particular nature imaginary, based on ancient traditional beliefs for sure, but influenced by historically recent events, and deeply concerned about the future.

In other geographical settings, nature imaginaries will take different forms. For example, mainland European cultures generally operate with a conception of landscape that acknowledges the cultural imprint of land use on nature through history. This may have eased the recent remaking of agricultural landscapes in Northern Germany into wind energy landscapes (Krauss, 2010), and can be seen as involving a particular nature imaginary.

Such constructs can thus matter greatly when it comes to the deployment of renewable energy. Through them, humannonhuman relations are crafted: imagining the future is 
a performative act. Crucially, nonhuman agency, through various affects of the diverse things that comprise nature, is an integral participant in the act of imagining these relations. In the remainder of the article, I will explore the analytical value of this approach with a discussion of the Icelandic energy transition, and of the formation and ongoing contest of different imaginaries in this particular context.

\section{Conflicting imaginings? The case of renewable energy in Iceland}

\subsection{The Icelandic energy mix: transition achieved?}

Iceland's position regarding both energy production and use is quite different from that of its neighbours (Benediktsson and Waage, 2018). Climate, terrain and hydrological conditions create abundant possibilities from an engineering point of view for hydroelectricity and wind energy. Added to this are the geological peculiarities of the country. The geothermal gradient - the rise in temperature with subsurface depth - is high, not only in the currently active volcanic zones but also in many other areas (Arnórsson, 2017). High temperature fields are found only in the volcanically active zones that stretch from the southwest to the northeast, whereas low temperature fields are scattered over much of the country (Fig. 1).

Estimations of energy that would be technically able to be harnessed from these two major streams - hydro and geothermal - give figures in the vicinity of 60-70 TWh per annum for each (National Energy Authority and Ministries of Industry and Commerce, 2006). Notably though, these figures do not take into account the myriad constraints that exist, neither economic nor environmental. This notwithstanding, and especially when wind energy - still almost entirely untapped (Benediktsson and Waage, 2018) is added, Iceland seems exceptionally well endowed with renewable energy sources.

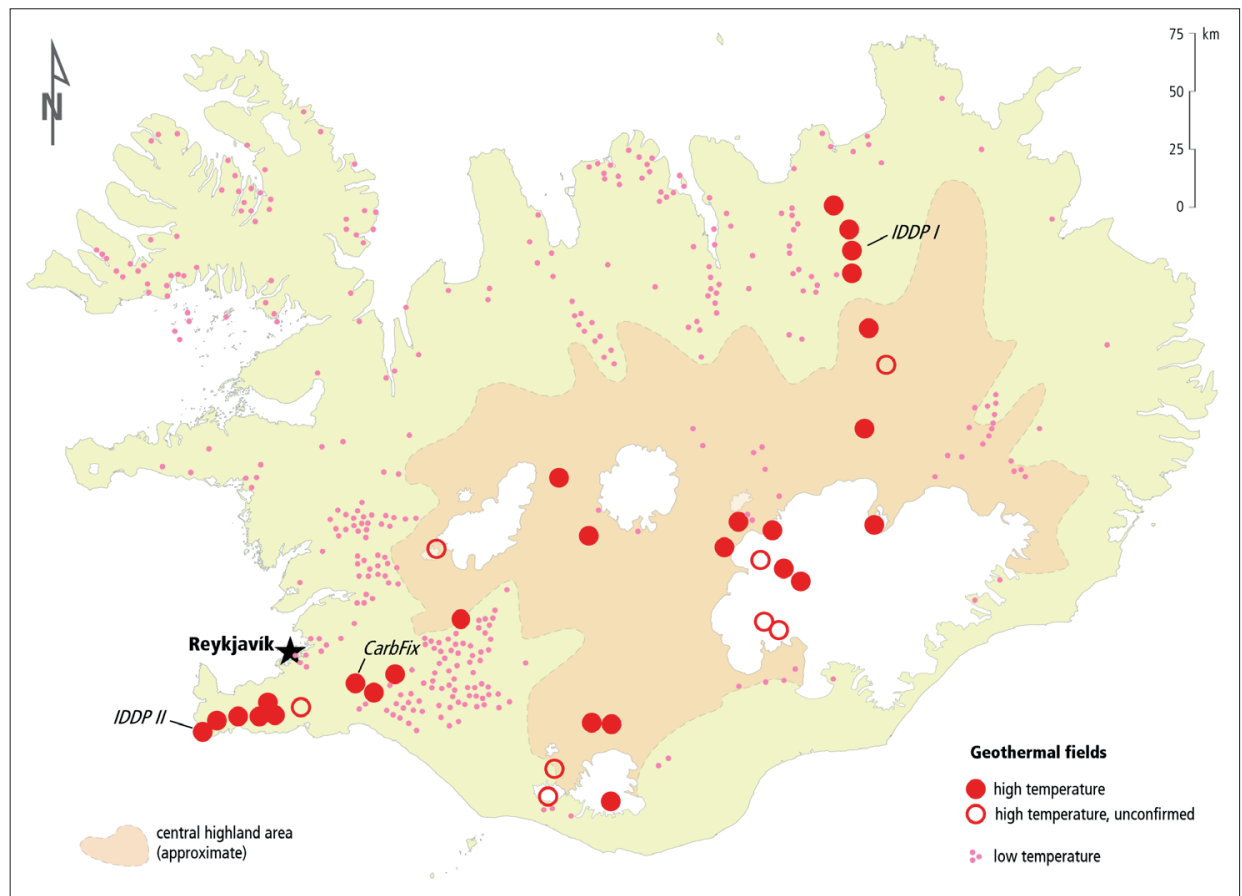

Fig. 1: Geothermal fields in Iceland. Also shown are the locations of innovation projects mentioned in the text Source: Porgeirsdóttir et al. (2015); map made by the author

At the beginning of the $20^{\text {th }}$ century the country was overwhelmingly rural, relying on the traditional energy sources of a subsistence economy. With economic changes and urbanisation as the century progressed, the need for energy grew tremendously (see Fig. 2). At the very start of this transformation, it seemed that imported fossil fuels - coal and oil - would prevail, but electricity soon won the technological contest. Numerous mostly rather small hydropower stations were built. In the late $1960 \mathrm{~s}$, the first large one was constructed on one of the glacial rivers. Its construction was linked to the building of the country's first aluminium smelter (Skúlason and Hayter, 1998). Further development of large-scale hydropower has followed, culminating in the Kárahnjúkar dam and power station (690 MW), commissioned in 2007 (Karlsdóttir, 2010).

Geothermal utilisation has developed differently. In addition to traditional localised use of geothermal water for bathing, it became increasingly used for the heating of indoor spaces during the $20^{\text {th }}$ century (Pálmason, 2005).

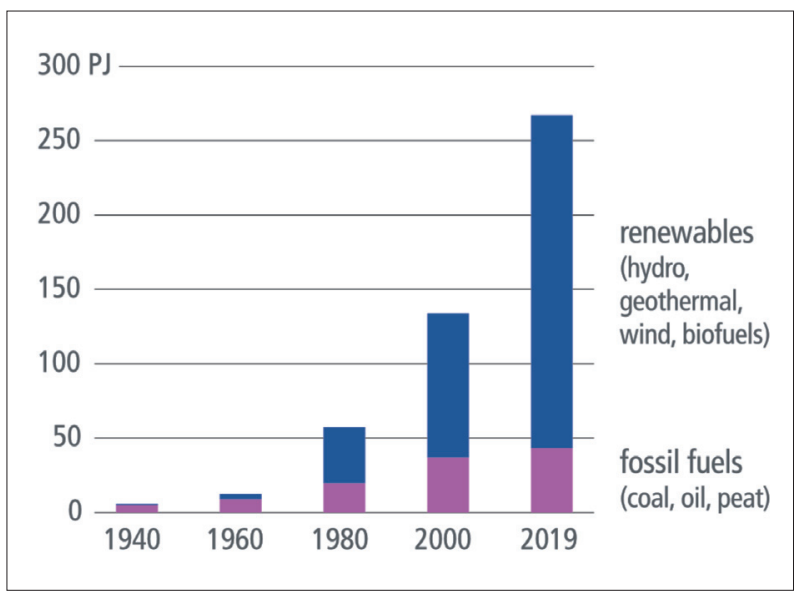

Fig. 2: Primary energy in Iceland 1940-2019

Source: Data from National Energy Authority (2020); graph made by the author 
Now about $90 \%$ of homes and other buildings are heated with geothermal water, the remainder mostly using electricity from both hydropower and geothermal power stations for heating (National Energy Authority, 2019). Electricity production from geothermal sources is the most recent addition. The current energy mix indicates the vigorous development of renewables: fossil fuels now account for less than $20 \%$ of all primary energy in Iceland, whereas $80-85 \%$ comes from renewable sources (Fig. 3). Land transportation, aviation, fisheries and shipping remain dependent on oil and thus linked into the global 'carbonscape'.

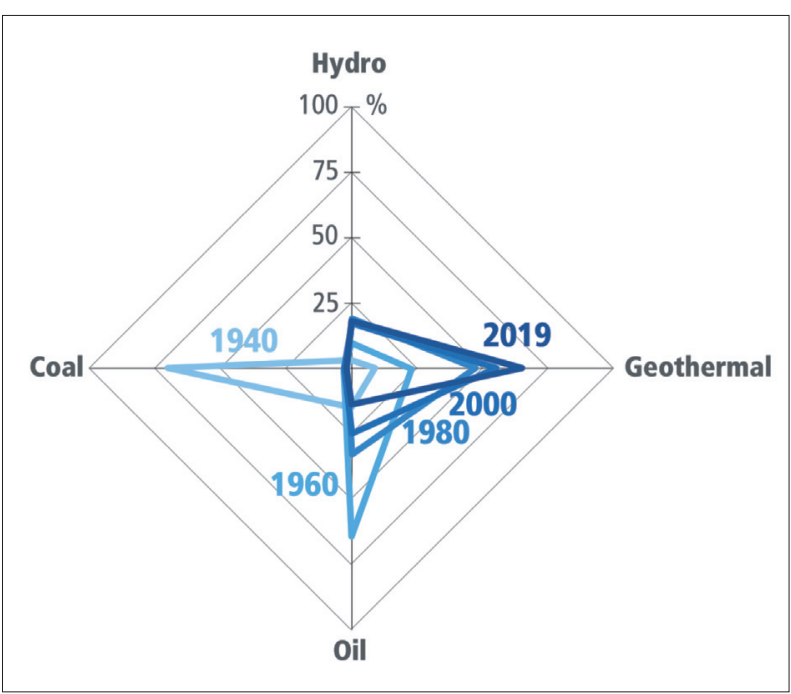

Fig. 3: The changing Icelandic primary energy mix Source: Data from National Energy Authority (2020); graph made by the author

\subsection{A geothermal sociotechnical imaginary}

A new chapter in the history of geothermal energy commenced in the 1960s with the building of a small power station in northeast Iceland. Some years later, planning started for a much larger station close by. Construction began, but nature intervened: in 1975 a spate of volcanic eruptions started in the area, causing considerable delays (Ármannsson et al., 1987). Eventually the station started producing, however. Another geothermal station was successfully built in the 1970s in the southwest, without any subterranean interventions. Knowledge relating to things geothermal had started to accumulate, and Iceland's geoscientists and engineers gradually gained a reputation for expertise in this specialised field. In 1979 for example, Iceland's National Energy Authority became the host for a Geothermal Training Programme for trainees from developing countries, under the auspices of the United Nations (GRÓ-GTP, n.d.)

In the 1990s the political direction of the Icelandic government changed firmly towards neoliberalism (Benediktsson, 2014). This resulted in a far-reaching change in policies and visions pertaining to energy resources and their utilisation, not least geothermal resources. Cheap electricity became a trump card in the global game of national competitiveness. A new campaign was started for aggressively marketing the country as a location for energyintensive industries (Guðmundsdóttir et al., 2018). In itself this was not entirely new, but the ideological change led to a much more concerted effort and contributed to the formation of a distinctive sociotechnical imaginary that centres on geothermal energy.
In 1990 the public utility company operating the district heating system of Reykjavík had gradually taken new hightemperature geothermal fields into use for the growing city, supplying both hot water and electricity from a new power station (Pálmason, 2005). This was a success. The company started planning for a much larger geothermal station some distance away, utilising the same geothermal field, albeit on the other side of the volcanic massif (Guðmundsdóttir et al., 2018). Another energy company also started constructing a new station in the southwest. Although in public ownership and originally set up to provide vital public services, both companies had adopted aggressive marketoriented strategies, eyeing good profitability with the selling of comparatively cheap geothermal electricity, marketed as 'clean and green', to bulk users.

In the first decade of the $21^{\text {st }}$ century, tremendous optimism was thus in the air regarding Iceland's energy future in general, bolstered by grand proclamations of industry proponents about the country becoming a "Kuwait of the North" (Magnason, 2008, p. 198). Promoted by the power companies and supported by political heavyweights and mainstream media, it also became a part of the financial (mis)adventures that characterised Iceland at the time (Benediktsson, 2014). The tone of a newspaper editorial in 2006 provides a good example. The editor boldly states: "Nowhere has geothermal energy been harnessed to greater extent than in Iceland, and therefore no people have more ingenuity or better technology than Icelanders for exploiting it" (Anon., 2006, p. 26). In an interview a year later, the thenPresident of Iceland Ólafur Ragnar Grímsson no less boldly stated his opinion that Icelanders had by then "outstanding technical and commercial knowhow in this field, and there is no other nation in the world that comes close, we are the absolute leader nation" (Anon., 2007)

Impressive technological innovation, alleged financial acumen, and a perception of almost limitless potential for growth thus became components in a formative geothermal sociotechnical imaginary that often has found expression in rather nationalistic rhetoric.

This imaginary has been further strengthened with a host of innovative research-and-development projects. One is the Iceland Deep Drilling Project. A large research project, still in progress, it is a joint undertaking of public and private interests. In addition to the three largest Icelandic energy companies, large international players have joined the project, notably Statoil from Norway, the US National Science Foundation, and the aluminium giant Alcoa (IDDP, 2020). The project aims at exploring whether it is possible to access geothermal fluids under 'supercritical' conditions at much greater depth than that of ordinary geothermal wells, potentially giving access to energy at a scale previously unknown in geothermal fields. The first well, in the northeast of the country, was intended to reach a depth of $4.5 \mathrm{~km}$, but drilling abruptly came to a halt at a depth of only $2.1 \mathrm{~km}$ when magma entered the borehole (Elders et al., 2014). The second IDDP borehole has since been drilled in the southwest (see Fig. 1), reaching the depth of 4,659 $\mathrm{m}$ in early 2017 (Friðleifsson et al., 2017), the temperature $\left(427^{\circ} \mathrm{C}\right.$ ) and pressure (340 bars) indicating that supercritical conditions had indeed been reached. At the time of writing, this well was undergoing flow testing.

Yet another and no less interesting strand has been added in recent years to the Icelandic geothermal imaginary. This is the so-called CarbFix project (CarbFix, 2019), a research project aimed at developing methods for sequestering 
carbon by dissolving $\mathrm{CO}_{2}$ in geothermal water and pumping it into the basaltic bedrock, where the carbon is mineralised as limestone. Geological conditions make the country particularly suitable for the process, but basalts are worldwide mainly found in volcanic areas and where the oceanic crust has formed through plate spreading. While subterranean carbon storage is not a completely new technology, the association with geothermal power production is novel. The technique has been proven to work very well (Matter et al., 2016). Numerous international media quickly picked up the story, some employing rather hyperbolic headlines proclaiming that $\mathrm{CO}_{2}$ had been "turned into stone" and declaring this as nothing less than a "climate change breakthrough" (Carrington, 2016). The current impact is somewhat more modest, yet significant: the geothermal power station where the CarbFix project is located (see Fig. 1) is already sequestering a substantial part of the carbon that would otherwise be emitted by the plant itself. With prices of emission quotas rising rapidly on the European market (Hodgson, 2020), there are those who hope that the method will make Iceland an even more competitive location for $\mathrm{CO}_{2}$-emitting heavy industry, providing unique opportunities for corporate actors to fix carbon in rock instead of having to buy expensive quotas. The experiment is thus intimately linked to the neoliberal financialisation of carbon that has been taking shape in recent years.

These are some of the developments that have led to the consolidation of a distinctive geothermal sociotechnical imaginary in Iceland: an imaginary that presents a future of almost unlimited geothermal energy with minimal environmental costs for the country, and even the potential for contributing with 'geoengineering' to address the most serious problem facing humankind: climate change. The imaginary is amply manifested in political, scientific and media discourses, as the glimpses provided above have shown. At its heart is an increasingly sophisticated 'technoepistemic network' (Ballo, 2015) that embraces the narrative of ecological modernisation. New geothermal energy projects continue to be planned, the realisation of which will have corresponding imprints on the landscape. Twisting the title of Jasanoff and Kim's edited book (2015), one could perhaps talk about an emerging 'steamscape of modernity' that invokes a certain kind of aesthetic sensibility (Fig. 4).

\subsection{The 'natural' landscape: an Icelandic nature imaginary}

Concurrently with the formation of the geothermal sociotechnical imaginary outlined above, a different moral vision of nature has become increasingly prominent among sections of the public - a preservationist one. It is not specifically focused on the geothermal; in fact, hydropower projects have been somewhat more influential in the formation of this nature imaginary, as will be explained further below.

The nature imaginary has its roots in part in the imagining of Iceland's interior highlands as a sacred space of 'untouched wilderness' that was cemented as the $20^{\text {th }}$ century progressed, but which can be traced much further back (Sæpórsdóttir, Hall and Saarinen, 2011). While the highlands had been frequently traversed during the first centuries of settlement, they took on an image of mystery and even terror and were generally an area to be avoided. This started to change with the rise of nationalism and Romanticism in the $19^{\text {th }}$ century, which laid the groundwork for the prominent position that the natural landscape has since held in the island's culture. During the $20^{\text {th }}$ century, new travel technologies opened up the highland landscapes to domestic recreation (Huijbens and Benediktsson, 2015). The surging international popularity of Iceland as a tourist destination in the $21^{\text {st }}$ century has played right into this imaginary (Karlsdóttir, 2013). Compared with densely populated mainland Europe, Icelandic nature indeed appears rather empty, wild, and 'raw', and this has been used by tourist promoters in a skillful manner.

The first clashes between preservationists and energy proponents occurred during the first half of the $20^{\text {th }}$ century (Karlsdóttir, 2010). These centred on hydropower, as ambitious plans were aired for harnessing some of Iceland's largest waterfalls. The plans were withdrawn, but hydropower development continued at more modest scales. In 1970 a major conflict between a public

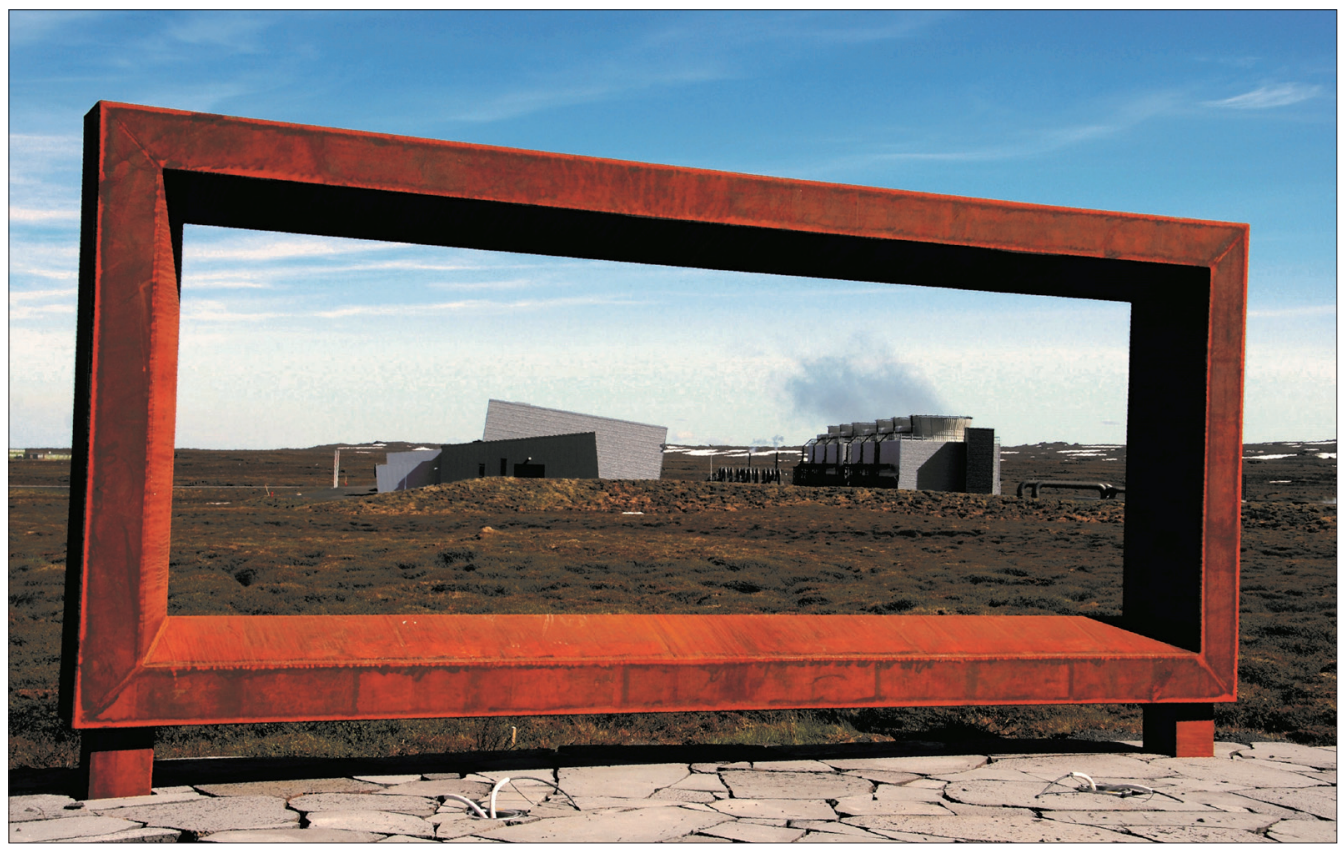

Fig. 4: The geothermal picturesque? New power station at Theistareykir, NE-Iceland Photo: Karl Benediktsson 
hydropower company and local farmers arose in the north (Karlsdóttir, 2010), often said to mark the beginning of the environmental movement in Iceland. But it was not until the 1990 s that the radically contrasting visions for the future massive energy development on the one hand and landscape and nature preservation on the other - came head-to-head (Benediktsson, 2007, 2008). Apart from concerns about the impacts of new reservoirs and altered hydrological conditions on nonhuman life, the prospect of subjecting large swathes of hitherto 'untouched wilderness' areas to human construction was alarming to preservationists (Karlsdóttir, 2010).

This history of intense hydropower conflicts may explain why, well into this century, environmental activists seemed to think that geothermal energy was a more benign option than hydropower (cf. Guðmundsson, 2005). This is debatable. It is true that as large reservoirs do not accompany geothermal power stations, and their physical footprint on the landscape is usually smaller (Trainor et al., 2016). Yet, while localised, the direct landscape impacts of geothermal energy are considerable. These include borehole platforms, wellheads, a spaghetti of pipelines, and various other industrial-looking contraptions (Benediktsson, 2018). Added to this is the fact that the natural geothermal surface activity can be affected. Such landscape manifestations of geothermal activity are globally rare, and they are supposed to enjoy special protection in the Icelandic Nature Conservation Act (Alpingi, 2013) Concerns have been frequently aired about the expansion of the geothermal industry into new high-temperature fields. Reckless exploitation of some geothermal fields has also brought home what some geologists (Pálmason, 2005; Arnórsson, 2017) have actually argued for a long time: that geothermal energy production may in fact be more akin to the 'thermal mining' of a stock resource than tapping into a truly renewable flow resource.

Lastly, geothermal harnessing is accompanied by some emission of substances that are harmful to local environments, such as mercury and hydrogen sulphide or the global climate, notably carbon dioxide and methane
(Kristmannsdóttir and Ármannsson, 2003). The release of greenhouse gases is very limited, however, compared with fossil fuel plants.

The strong association of these developments with heavy industry has increasingly led to the contestation of the very purpose of further energy development (Magnason, 2008; Guðmundsdóttir et al., 2018). Iceland currently tops the global list of nations in electricity consumption per capita, but in fact about $80 \%$ of all electricity produced in the country is used by a handful of industrial facilities (Benediktsson and Waage, 2018), three aluminium smelters being by far the largest consumers. The inherently dirty nature of these industries has been mostly glossed over in the rush to capitalise on the green image of Icelandic energy actually the country's $\mathrm{CO}_{2}$ emissions have increased very substantially since the development of heavy industry began (Guðmundsdóttir et al., 2018). The argument that the country would be doing the world a favour by attracting more heavy industry is summarily dismissed by those concerned with more and more local landscapes being subjected to demands of production for a voracious global market. The search for new large users has continued, but not the emphasis on other industries, such as silicon factories and especially data centres (Landsvirkjun, n.d.). The latter class of users has been growing rapidly, largely due to the mining of Bitcoin and other cryptocurrencies. Questions are being asked about the morality of allocating more and more resources to power production for this end (Eiríksdóttir, 2019).

A morally-imbued nature imaginary that centres on landscape thus seems to have taken shape. Having deep historical roots, it has been cemented through repeated confrontation with energy interests and their expressions. The idea of pristine, untouched wilderness is central to this nature imaginary (Ólafsdóttir and Sæpórsdóttir, 2020). The emphasis is on the tremendous intrinsic value of wild landscapes, which, it is argued, offer essential yet ever scarcer opportunities for humans to experience such landscapes and be affected by their nature (Fig. 5). The imagining of the country's landscapes as 'untouched' is in fact rather fanciful - they have after all been thoroughly affected by

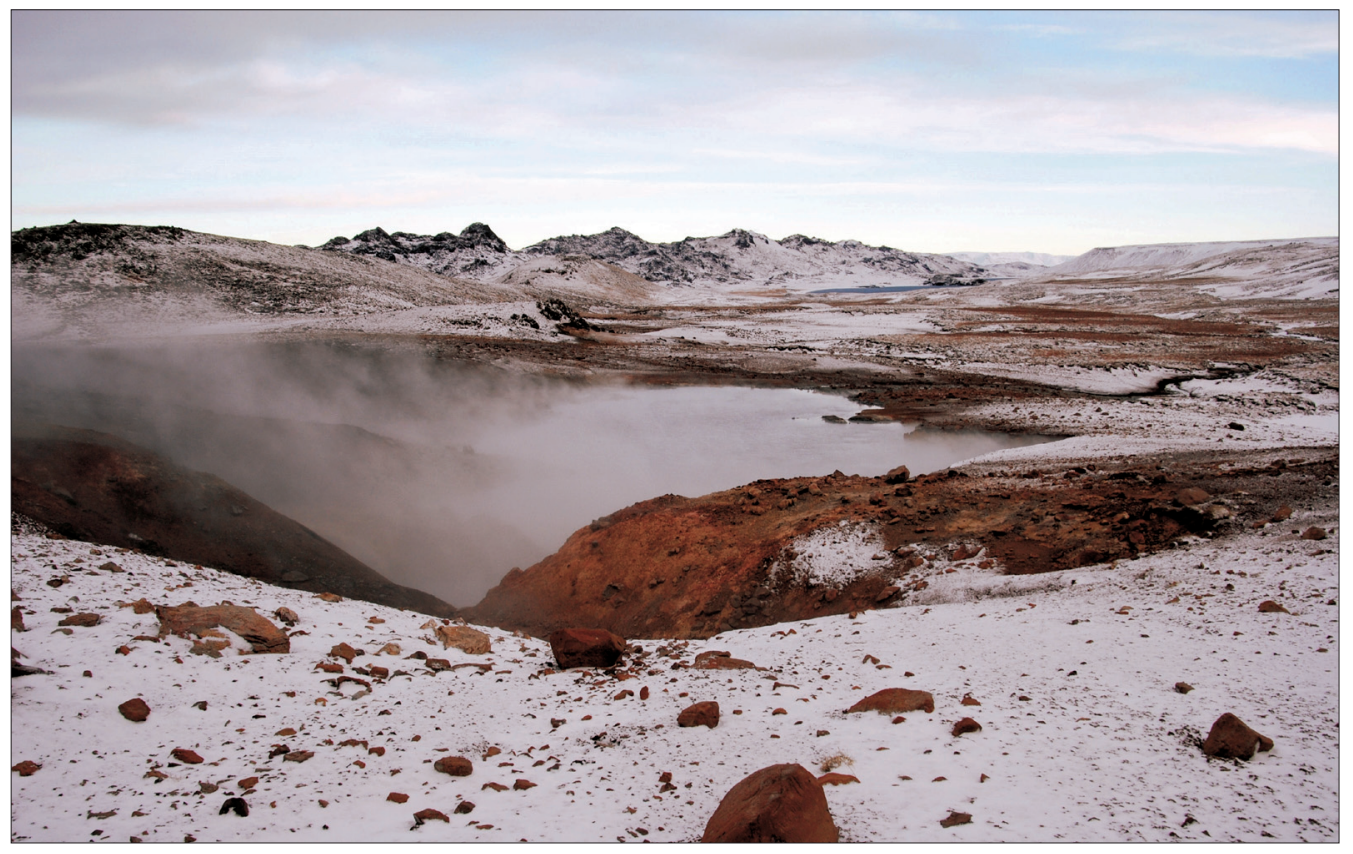

Fig. 5: Austurengjahver, a proposed site for a geothermal power station in SW-Iceland Photo: Karl Benediktsson 
a millennium of human exploitation. Partly in recognition of this, the expression 'untouched wilderness' is now rather avoided in policy and legal documents, but it remains part of the vocabulary of many preservationists.

Another and no less important component in the formation of this nature imaginary is nationalism, which has been a prominent theme in the Icelandic environmental movement since it started to take shape (Jóhannesson, 2005; Karlsdóttir, 2010). In fact, at the turn of the century a prominent historian argued that nature had largely taken over from language as a signifier of Icelandic national identity (Hálfdanarson, 1999). Many protests against hydropower projects have involved strategies that appeal to nationalist sentiments, such as the planting of Icelandic flags into a geothermal area to be submerged under a hydropower reservoir, and the laying of stones containing words from the national anthem at another reservoir site (Brydon, 2010).

These sentiments are expressed by various groups: lay people, natural scientists, writers and artists. In fact, artists have played a large part in articulating the moral critique implicit in the nature imaginary, for example through visual artworks, installations, and land art (Brydon, 2010; Gremaud, 2014, 2017). Arguably, art has provided a way to give a particularly strong expression to the affective relations between Icelanders and non-human nature. A case in point is the work Archive - Endangered waters by artist Rúrí, analysed by Brydon (2010, p. 202). In this visual/aural work, first exhibited at the 2003 Venice Biennale and later in Iceland, the artist 'gave voice' to some 52 waterfalls that would be silenced - either emptied or submerged - if the numerous planned hydropower projects went ahead.

In sum, for those who have shaped and adopted the landscape-focused nature imaginary and see it as central to a morally proper future, further large-scale energy projects to produce power for the already sizeable heavy industry sector are seen as a decidedly wrong way for Icelanders to relate to the nonhuman nature with which they live. Although geothermal technology is still somewhat less contested than hydropower, the now-apparent substantial environmental impacts of geothermal electricity production have added to already existing concerns about landscape and nature.

\section{Conclusion: Imagining energy futures}

In this article I have argued that for understanding geographically diverse energy transition trajectories we need to contemplate how the social, the technical, and the natural fold into each other in varied ways through the imaginative futures that every society constructs, not only at the national level, but also within smaller social and geographical communities. At work are not only monolithic national sociotechnical imaginaries, but also nature imaginaries that concern the proper place of nonhuman nature for future human society.

This approach certainly has its limits. Inherent in these concepts of imaginaries is a tension between stability and change, which has not been fully resolved. Even if they are meant as help for understanding processes of temporal change and geographical diversity, they may still project rather too much stability. Imaginaries are analysed as stabilisations; sedimented world views and discourses that appear as static. While the study of nature imaginaries in addition to sociotechnical ones adds substantially to the understanding of energy transitions, both must be understood as only ever temporary solidifications of thoughts and practices that are far from immutable.

The analysis of the Icelandic imaginaries offered here is also somewhat limited, based as it is on a tentative interpretation of certain elements of national discourses, and the author's own observations through the years of Icelandic nature- and landscape-related conflicts. Yet some interesting suggestions emerge that support the hypothesis that aligning or mismatching imaginaries do influence energy transitions.

Renewable energy in Iceland is often seen as a spectacular success story, and with some justification. The country's energy landscape is the result of links between nature, scientists, technologies, corporations, and myriad other actors. But even here the energy transition is not completed, and questions remain about some aspects of its seemingly smooth progress. A distinctive sociotechnical imaginary is now in place, one which forcefully presents the continuing expansion of energy production as a moral obligation to provide the world with 'green', carbon-free energy. This is most strongly expressed in the geothermal sector, a site of intense technoscientific innovation. New experiments even present the possibility to mitigate climate change by returning carbon back to the earth. In recent years, a strong 'technological fix' approach has been evident. To be fair, some of the scientific protagonists of this exciting technology have duly acknowledged its limitations for tackling the scourge of global warming. Left mostly undiscussed, however, is the lingering concern that the enthusiasm for 'engineering Earth' (cf. Brunn, 2010), which includes even grander ideas of 'climate engineering' on a planetary scale, may not be the wisest response of mankind to this pressing problem (Hulme, 2014; Nightingale et al., 2020).

A particular nature imaginary has also emerged, that questions the very premises upon which the recent and ongoing expansion of the energy sector rests. Here the affective potential of wild landscapes assumes centre stage: the capacity of humans to be affected through encounters with nature 'in the raw'. This imaginary gains its expressive power from ideas about moral obligations to present and future generations - this time about the immense experiential value of landscapes and nature that is left without the marks of technological intervention. Added to this emphasis on wilderness landscapes are serious misgivings about the neoliberal approach to managing natural resources that is inherent in the current energy regime. This nature imaginary, although not undisputed, acts as a constraint on further expansion of the energy sector. Despite its basis in environmental concerns, however, it does not connect strongly with discourses of global climate change and any possibilities for halting it or slowing it down.

In this case, where technoscientific euphoria faces the glorification of the wild, adherents of both imaginaries could benefit from a more critical stance towards their own foundational ideas. Icelanders cannot pretentiously claim to be able to fix the global climate crisis on their own, but neither can they abstain from global responsibility when it comes to renewable energy. The crucial question is how such different and perhaps incompatible mental envisionings will affect the future development of the renewable energy landscape. Such development will not only be about the currently most significant energy technologies, geothermal and hydro, but also about other forms of renewable energy, most obviously wind energy. Several wind projects are 
entering the planning stage. While there is no doubt that the aeolian conditions are extremely favourable, the landscape impacts of those projects, if realised, will be very significant. It is easy to anticipate a clash with the prevailing nature imaginary. Negotiating this new terrain will require new and sensitive methods for the evaluation of local impacts (Frantál et al., 2017).

Most importantly, acknowledgement and respect of differing imaginaries is a necessary condition for advancing the energy transition. Social imaginaries are surely never static, but constantly undergoing modification. A frank discussion about the ideological and cultural basis of both 'Icelandic' imaginaries is a precondition to their gradual adjustment, or a more radical re-imagining of relations between society, technology, and nature. This could allow for continued development of renewables without irrevocable loss of values to do with nature and landscape. This will not come about through top-down decrees: an open and democratic exchange is needed for the cultivation of new imaginaries.

A wider conclusion to be drawn is perhaps this: the realisation of a renewable energy future globally does not only depend on local physical contexts and available technical knowledge, but also on imaginaries that open new possibilities - or prevent their realisation. I have argued that nonhuman nature needs to be taken seriously in this aspect of energy transitions, in part through its often-veiled role in sociotechnical imaginaries, but also through the formation of specific nature imaginaries that may either be roughly in tune with sociotechnical imaginings or not. The analysis of how diverse imaginaries, contested and conflicting, may be at work in country-specific energy transitions might help in identifying leverage points from which it is possible to work in a small way towards the global transition that is so urgently needed.

\section{Acknowledgements}

This article is rooted in the author's participation in the EU network 'Renewable Energy and Landscape Quality' (COST-Action TU-1402, http://cost-rely.eu/), and different aspects of it have been presented at several international conferences and workshops. The author is thankful for useful feedback at these occasions. Edda $R$. H. Waage is thanked for thoughtful comments on a draft. Generous thanks are also due to the reviewers and editors.

\section{References:}

ALCOA (2020): Alcoa-Iceland [online]. [cit. 08.12.2020] Available at: https://www.alcoa.com/iceland/ic

ALPINGI (2013) Lög um náttúruvernd [Nature Conservation Act] nr. 60/2013 [online]. [cit. 06.10.2020]. Available at: https://www.althingi.is/lagas/nuna/2013060.html

ANDERSON, B. (1983): Imagined Communities: Reflections on the Origin and Spread of Nationalism. London, Verso.

Anon. (2006): Útrás orkugeirans. Morgunblaðið, 5.12.2006 [online]. [cit. 01.10.2020]. Available at: https://www.mbl. is/greinasafn/grein/1117808/

Anon. (2007): Gæti skapað meiri verðmæti en útrás bankanna. Vísir, 8.4.2007 [online]. [cit. 01.10.2020]. Available at: https://www.visir.is/g/200770408036

APOSTOL, D., PALMER, J., PASQUALETTI, M., SMARDON, R., SULLIVAN, R. [eds.] (2016): The
Renewable Energy Landscape: Preserving Scenic Values in our Sustainable Future. Oxford, Routledge.

APPADURAI, A. (1996): Modernity at Large: Cultural Dimensions of Globalization. Minneapolis, University of Minnesota Press.

ÁRMANNSSON, H., GUDMUNDSSON, A., STEINGRÍMSSON, B. S. (1987): Exploration and development of the Krafla geothermal area. Jökull 37: 13-30.

ARNÓRSSON, S. (2017): Jarðhiti og jarðarauðlindir. Reykjavík, Hiđ íslenska bókmenntafélag.

BALLO, I. F. (2015): Imagining energy futures: Sociotechnical imaginaries of the future Smart Grid in Norway. Energy Research and Social Science, 9: 9-20.

BENEDIKTSSON, K. (2007): "Scenophobia", geography and the aesthetic politics of landscape. Geografiska Annaler B: Human Geography, 89(3): 203-217.

BENEDIKTSSON, K. (2008): Moving places: the emotional politics of nature. In: Bærenholdt, J. O., Granås, B. [eds]: Mobility and Place: Enacting Northern European Mobilities (pp. 205-217). Aldershot, Ashgate.

BENEDIKTSSON, K. (2014): Nature in the 'neoliberal laboratory'. Dialogues in Human Geography, 4(2): 141-146.

BENEDIKTSSON, K. (2018): Geothermal energy. In: Roth, M. et al. [eds]: Renewable energy and landscape quality (pp. 122-127). Berlin, JOVIS Verlag.

BENEDIKTSSON, K., WAAGE, E. R. H. (2018): Iceland. In: Roth, M. et al. [eds.]: Renewable energy and landscape quality (pp. 48-51). Berlin, JOVIS Verlag.

BENEDIKTSSON，K., WAAGE，E.R.H. (2020): Power without politics? Nature, landscape and renewable energy in Iceland. Annales de Géographie, 736: 107-130.

BENNETT, J. (2004): The force of things: Steps toward an ecology of matter. Political Theory, 32(3): 347-372.

BRIDGE, G., BOUZAROVSKI, S., BRADSHAW, M., EYRE, N. (2013): Geographies of energy transition: Space, place and the low-carbon economy. Energy Policy, 53: 331-340.

BRUNN, S. (2010): Engineering Earth: The Impact of Megaengineering Projects (2 vols.). Dordrecht, Springer.

BRYDON, A. (2010): Sentience. In: Benediktsson, K., Lund, K. A. [eds]: Conversations with Landscape (pp. 193-209). Farnham, Ashgate.

BURNHAM, M., EATON, W., SELFA, T., HINRICHS, C., FELDPAUSCH-PARKER, A. (2017): The politics of imaginaries and bioenergy sub-niches in the emerging Northeast US bioenergy economy. Geoforum, 82: 66-76.

CARBFIX (2019): Carbfix [online]. [cit. 01.10.2020]. Available at: https://www.carbfix.com/

CARLEY, S., BALDWIN, E., MACLEAN, L. M., BRASS, J. N. (2017): Global expansion of renewable energy generation: an analysis of policy instruments. Environmental and Resource Economics, 68(2): 397-440.

CARRINGTON, D. (2016): $\mathrm{CO}_{2}$ turned into stone in Iceland in climate change breakthrough. The Guardian, 9.6.2016 [online]. [cit. 01.10.2020]. Available at: https://www. theguardian.com/environment/2016/jun/09/co2-turnedinto-stone-in-iceland-in-climate-change-breakthrough 
CASTORIADIS, C. (1987): The Imaginary Institution of Society. Cambridge, Polity Press.

CATTON Jr, W. R., DUNLAP, R. E. (1980): A new ecological paradigm for post-exuberant sociology. American Behavioral Scientist, 24(1): 15-47.

CLARK, N. (2011): Inhuman Nature: Sociable Life on a Dynamic Planet. London, SAGE Publications.

CLOKE, J., MOHR, A., BROWN, E. (2017): Imagining renewable energy: Towards a Social Energy Systems approach to community renewable energy projects in the Global South. Energy Research and Social Science, 31: 263-272.

COOLE, D., FROST, S. [eds.] (2010): New Materialisms: Ontology, Agency and Politics. Durham, Duke University Press.

DELANDA, M. (2016): Assemblage Theory. Edinburgh, Edinburgh University Press.

DELINA, L. L. (2018): Whose and what futures? Navigating the contested coproduction of Thailand's energy sociotechnical imaginaries. Energy Research and Social Science, 35: 48-56.

DELINA, L., JANETOS, A. (2018): Cosmopolitan, dynamic, and contested energy futures: navigating the pluralities and polarities in the energy systems of tomorrow. Energy Research and Social Science, 35: 1-10.

EATON，W. M., GASTEYER， S. P., BUSCH， L. (2014): Bioenergy futures: framing sociotechnical imaginaries in local places. Rural Sociology, 79(2): 227-256.

EIRÍKSDÓTTIR, T. (2019): Telur framleiðslu bitcoin sóun á raforku. RÚV 17.07.2019 [online]. [cit. 06.09.2020]. Available at: https://www.ruv.is/frett/telur-framleidslubitcoin-soun-a-raforku

ELDERS, W. A., FRIĐLEIFSSON, G. Ó., ALBERTSSON, A. (2014): Drilling into magma and the implications of the Iceland Deep Drilling Project (IDDP) for high-temperature geothermal systems worldwide. Geothermics, 49: 111-118.

FRANTÁL, B., BEVK, T., VAN VEELEN, B., HĂRMĂNESCU, M., BENEDIKTSSON, K. (2017): The importance of on-site evaluation for placing renewable energy in the landscape: A case study of the Búrfell wind farm (Iceland). Moravian Geographical Reports, 25(4): 234-247.

FRANTÁL, B., NOVÁKOVÁ, E. (2019): On the spatial differentiation of energy transitions: Exploring determinants of uneven wind energy developments in the Czech Republic. Moravian Geographical Reports, 27(2): 79-91.

FRIĐLEIFSSON, G. Ó., ELDERS, W. A. et al. (2017): The drilling of the Iceland Deep Drilling Project geothermal well at Reykjanes has been successfully completed [online]. [cit. 01.10.2020]. Available at: http://iddp.is/wpcontent/uploads/2017/02/IDDP-2-Completion-websitesIDDP-DEEPEGS2.pdf

GABRIEL, N. (2014): Urban political ecology: Environmental imaginary, governance, and the non-human. Geography Compass, 8(1): 38-48.

GREENHOUGH, B. (2014): More-than-human geographies. In: Lee, R. et al. [eds.]: The SAGE Handbook of Human Geography (pp. 94-119). London, SAGE.
GREMAUD, A-S. N. (2014): Power and purity: Nature as resource in a troubled society. Environmental Humanities, 5(1): 77-100.

GREMAUD, A. N. (2017): Icelandic futures: Arctic dreams and geographies of crisis. In: Körber, L. et al. [eds.]: Arctic Environmental Modernities: From the Age of Polar Exploration to the Era of the Anthropocene (pp. 197-213). Cham, Palgrave Macmillan.

GRÓ-GTP. (n.d.): The Geothermal Training Programme (GTP) [online] [cit. 06.10.2020]. Available at: https:// www.grocentre.is/gtp/about-gtp/mission

GUĐMUNDSDÓTTIR, H., CARTON, W., BUSCH, H., RAMASAR, V. (2018): Modernist dreams and green sagas: The neoliberal politics of Iceland's renewable energy economy. Environment and Planning E: Nature and Space, 1(4): 579-601.

GUĐMUNDSSON, J. (2005): Ísland örum skorið [editorial]. DV, 18 February, 2.

HÁLFDANARSON, G. (1999): „Hver á sér fegra föðurland“: Staða náttúrunnar í íslenskri bjóðernisvitund. Skírnir, 173: 304-336.

HODGSON, C. (2020): Price of EU carbon credits soars to 14-year high. Financial Times, 13.07.2020 [online]. [cit. 06.10.2020]. Available at: https://www.ft.com/content/ ab7abf9f-d05a-4c0c-85d8-96a4c0727603

HUIJBENS, E., BENEDIKTSSON, K. (2015): Automobile authorship of landscapes. In: Kolen, J., et al. [eds.]: Landscape Biographies: Geographical, Historical and Archaeological Perspectives on the Production and Transmission of Landscapes (pp. 99-116). Amsterdam, Amsterdam University Press.

HULME, M. (2014): Can Science Fix Climate Change? A Case against Climate Engineering. Cambridge: Polity Press.

HUNOLD, C., LEITNER, S. (2011): 'Hasta la vista, baby!' The Solar Grand Plan, environmentalism, and social constructions of the Mojave Desert. Environmental Politics, 20(5): 687-704.

IDDP [Iceland Deep Drilling Project] (2020): About [online]. [cit. 01.10.2020]. Available at: https://iddp.is/about/

IGNATOW, G. (2006): Cultural models of nature and society: reconsidering environmental attitudes and concern. Environment and Behavior, 38(4): 441-461.

IRENA (2020): Renewable Energy Statistics 2020 [online]. [cit. 05.10.2020]. Available at: https://www.irena.org/-/ media/Files/IRENA/Agency/Publication/2020/Jul/ IRENA_Renewable_Energy_Statistics_2020.pdf

JASANOFF, S. (2015): Future imperfect: science, technology, and the imaginations of modernity. In: Jasanoff, S., Kim, S-H. [eds.]: Dreamscapes of Modernity: Sociotechnical Imaginaries and the Fabrication of Power (pp. 1-33). Chicago, University of Chicago Press.

JASANOFF, S., KIM, S-H. (2009): Containing the atom: Sociotechnical imaginaries and nuclear power in the United States and South Korea. Minerva, 47(2): 119-146.

JASANOFF, S., KIM, S-H. [eds.] (2015): Dreamscapes of Modernity: Sociotechnical Imaginaries and the Fabrication of Power. Chicago, University of Chicago Press.

JÓHANNESSON, I. Á. (2005): Icelandic nationalism and the Kyoto Protocol: An analysis of the discourse on 
global environmental change in Iceland. Environmental Politics, 14(4): 495-509.

KAIKA, M., SWYNGEDOUW, E. (2011): The urbanization of nature: great promises, impasse, and new beginnings. In: Bridge, G., Watson, S. [eds.]: The New Blackwell Companion to the City (pp. 96-107). Oxford, Wiley-Blackwell.

KARLSDÓTTIR, U. B. (2010): Par sem fossarnir falla. Náttúrusýn og nýting fallvatna á Íslandi 1900-2008. Reykjavík, Hiđ íslenska bókmenntafélag.

KARLSDÓTTIR, U. B. (2013): Nature worth seeing! The tourist gaze as a factor in shaping views on nature in Iceland. Tourist Studies, 13(2): 139-155.

KIM, E. S., CHUNG, J. B., SEO, Y. (2018): Korean traditional beliefs and renewable energy transitions: Pungsu, shamanism, and the local perception of wind turbines. Energy Research and Social Science, 46: 262-273.

KRAUSS, W. (2010): The 'Dingpolitik' of wind energy in northern German landscapes: An ethnographic case study. Landscape Research, 35(2): 195-208.

KRISTMANNSDÓTTIR, H., ÁRMANNSSON, H. (2003): Environmental aspects of geothermal energy utilization. Geothermics, 32(4-6): 451-461.

KUCHLER, M., BRIDGE, G. (2018): Down the black hole: sustaining national socio-technical imaginaries of coal in Poland. Energy Research and Social Science, 41: 136-147.

LABUSSIÈRE, O., NADAÏ, A. [eds.] (2018): Energy Transitions: A Socio-Technical Inquiry. Cham, Palgrave Macmillan.

LANDSVIRKJUN (n.d.): Data centers in Iceland [online] [cit. 06.10.2020]. Available at: https://www.landsvirkjun. com/productsservices/data-centers/data-centers-iniceland/

LATOUR, B. (1987): Science in Action: Following Scientists and Engineers through Society. Cambridge MA, Harvard University Press.

LATOUR, B. (2005): Reassembling the Social: An Introduction to Actor-Network-Theory. Oxford, Oxford University Press.

LONGHURST, N., CHILVERS, J. (2019): Mapping diverse visions of energy transitions: co-producing sociotechnical imaginaries. Sustainability Science, 14(4): 973-990.

MAGNASON, A. S. (2008): Dreamland: A Self-Help Manual for a Frightened Nation. London, Citizen Press.

MARCUS, G. [ed.] (1995): Technoscientific Imaginaries: Conversations, Profiles, and Memoirs. Chicago, University of Chicago Press.

MARX, L. (1964): The Machine in the Garden: Technology and the Pastoral Ideal in America. New York, Oxford University Press.

MATTER, J. M., STUTE, M. et al. (2016): Rapid carbon mineralization for permanent disposal of anthropogenic carbon dioxide emissions. Science, 352(6291): 1312-1314.

MCGREGOR, A. (2004): Sustainable development and 'warm fuzzy feelings': discourse and nature within Australian environmental imaginaries. Geoforum, 35(5): 593-606.

MILLINGTON, N. (2013): Post-industrial imaginaries: Nature, representation and ruin in Detroit, Michigan. International Journal of Urban and Regional Research, 37(1): 279-296.
NATIONAL ENERGY AUTHORITY (2019): OS2019-T012-01: Space heating by energy source [data file].

NATIONAL ENERGY AUTHORITY (2020): OS2020-T007-02: Primary Energy Use in Iceland 19402019 [data file].

NATIONAL ENERGY AUTHORITY, MINISTRIES OF INDUSTRY AND COMMERCE (2006): Energy in Iceland: Historical Perspective, Present Status, Future Outlook. Reykjavík, National Energy Authority and Ministries of Industry and Commerce.

NEOFYTOU, H., NIKAS, A., DOUKAS, H. (2020): Sustainable energy transition readiness: A multicriteria assessment index. Renewable and Sustainable Energy Reviews, 131, 109988 [online]. [cit. 03.10.2020]. Available at: https://doi.org/10.1016/j.rser.2020.109988

NESBITT, J. T., WEINER, D. (2001): Conflicting environmental imaginaries and the politics of nature in Central Appalachia. Geoforum, 32(3): 333-349.

NIGHTINGALE, A. J., ERIKSEN, S., TAYLOR, M., FORSYTH, T., PELLING, M., NEWSHAM, A., BOYD, E., BROWN, K., HARVEY, B., JONES, L., BEZNER KERR, R., MEHTA, L., NAESS, L. O., OCKWELL, D., SCOONES, I, TANNER, T, WHITFIELD, S. (2020): Beyond technical fixes: climate solutions and the great derangement. Climate and Development, 12(4): 343-352.

NYE, D. (1990): Electrifying America: Social Meanings of a New Technology. Cambridge MA, MIT Press.

ÓLAFSDÓTTIR, R., SÆPÓRSDÓTTIR, A. D. (2020): Public perception of wilderness in Iceland. Land, 9(99) [online]. [cit. 01.10.2020]. Available at: https://doi.org/10.3390/ land9040099

PÁLMASON, G. (2005): Jarðhitabók - Eðli og nýting auðlindar. Reykjavík, Hið íslenska bókmenntafélag.

PASQUALETTI， M. J., STREMKE， S. (2018): Energy landscapes in a crowded world: a first typology of origins and expressions. Energy Research and Social Science, 36: $94-105$.

PEET, R., WATTS, M. (1996): Liberation ecology: development, sustainability, and environment in an age of market triumphalism. In: Peet, R., Watts, M. [eds.]: Liberation Ecologies: Environment, Development, Social movements (pp. 1-45). London, Routledge.

PETERSEN, L. K. (2018): Engaging with nature through the dwelling practices in garden landscapes. Social \& Cultural Geography [online]. [cit. 03.10.2020]. Available at: https://doi.org/10.1080/14649365.2018.1550803

ROLSTON III, H. (1987): Can the East help the West to value nature? Philosophy East and West, 37: 172-190.

ROTH, M., EITER, S. RÖHNER, S., KRUSE, A., SCHMITZ, S., FRANTÁL, B., CENTERI, C., FROLOVA, M., BUCHECKER, M., STOBER, D., KARAN, I., VAN DER HORST, D. [eds.] (2018): Renewable Energy and Landscape Quality. Berlin, JOVIS Verlag.

SARRICA, M., BRONDI, S., COTTONE, P., MAZZARA. B. M. (2016): One, no one, one hundred thousand energy transitions in Europe: The quest for a cultural approach. Energy Research and Social Science, 13: 1-14.

SCHELHAS, J., HITCHNER, S., BROSIUS, J. P. (2018): Envisioning and implementing wood-based bioenergy systems in the Southern United States: Imaginaries 
in everyday talk. Energy Research and Social science, 35: 182-192.

SELMAN, P. (2010): Learning to love the landscapes of carbon-neutrality. Landscape Research, 35(2): 157-171.

SKÚLASON, J. B., HAYTER, R. (1998): Industrial location as a bargain: Iceland and the aluminium multinationals 1962-1994. Geografiska Annaler B: Human Geography, 80(1): 29-48.

SMITH, M. R., MARX, L. [eds.] (1994): Does Technology Drive History? The Dilemma of Technological Determinism. Cambridge MA, MIT Press.

SMITH, J. M., TIDWELL, A. S. (2016): The everyday lives of energy transitions: Contested sociotechnical imaginaries in the American West. Social Studies of Science, 46(3): 327-350.

SOVACOOL，B. K., BROSSMANN，B. (2013): Fantastic futures and three American energy transitions. Science as Culture, 22(2): 204-212.

STEINBACHER, K. (2019): Exporting the Energiewende. German Renewable Energy Leadership and Policy Transfer. Wiesbaden, Springer VS.

STERN, P. C. (2000): New environmental theories: toward a coherent theory of environmentally significant behavior. Journal of Social Issues, 56(3): 407-424.

STRAUSS, C. (2006): The imaginary. Anthropological Theory, 6(3): 322-344.

SVOBODOVA, K., OWEN, J. R., HARRIS, J., WORDEN, S. (2020): Complexities and contradictions in the global energy transition: A re-evaluation of country-level factors and dependencies. Applied Energy, 265, 114778 [online]. [cit. 05.10.2020]. Available at: https://doi.org/10.1016/j. apenergy.2020.114778

SÆPÓRSDÓTTIR, A. D., HALL， C.M., SAARINEN，J. (2011): Making wilderness: tourism and the history of the wilderness idea in Iceland. Polar Geography, 34(4): 249-273.

TAYLOR, C. (2004): Modern Social Imaginaries. Durham, Duke University Press.

THRIFT, N. (2004): Intensities of feeling: towards a spatial politics of affect. Geografiska Annaler B: Human Geography, 86(1): 57-78.

TIDWELL， J.H., TIDWELL, A.S. (2018): Energy ideals, visions, narratives, and rhetoric: examining sociotechnical imaginaries theory and methodology in energy research. Energy Research and Social Science, 39: $103-107$.

TOZER, L., KLENK, N. (2018): Discourses of carbon neutrality and imaginaries of urban futures. Energy Research and Social Science, 35: 174-181.

TRAINOR, A. M., MCDONALD, R. I., FARGIONE, J. (2016): Energy sprawl is the largest driver of land use change in United States. PloS One, 11(9): e0162269 [online]. [cit.05.10.2020]. Available at: https://doi.org/10.1371/ journal.pone.0162269

VISIT EGILSSTAĐIR (n.d.): Kárahnjúkar Hydropower Plant [online]. [cit.08.12.2020]. Available at: https:// visitegilsstadir.is/en/things-to-see/karahnjukavirkjundam/

WHITE, L. (1967): The historical roots of our ecologic crisis. Science 155(3767): 1203-1207.

\section{Please cite this article as:}

BENEDIKTSSON, K. (2021): Conflicting imaginaries in the energy transition? Nature and renewable energy in Iceland. Moravian Geographical Reports, 29(2): 88-100. doi: https://doi.org/10.2478/mgr-2021-0008 